\title{
Considerations for Sustainable Biomass Production in Quercus-Dominated Forest Ecosystems
}

\author{
Viktor J. Bruckman, Shuai Yan, Eduard Hochbichler and Gerhard Glatzel
}

Additional information is available at the end of the chapter

http://dx.doi.org/10.5772/53518

\section{Introduction}

Our current energy system is mainly based on carbon (C) intensive metabolisms, resulting in great effects on the earth's biosphere. The majority of the energy sources are fossil (crude oil, coal, natural gas) and release $\mathrm{CO}_{2}$ in the combustion (oxidation) process which takes place during utilization of the energy. $\mathrm{C}$ released to the atmosphere was once sequestered by biomass over a time span of millions of years and is now being released back into the atmosphere within a period of just decades. Fossil energy is relatively cheap and has been fuelling the world economy since the industrial revolution. To date, fossil fuel emissions are still increasing despite a slight decrease in 2009 as a consequence of the world's economic crisis. Recently, the increase is driven by emerging economies, from the production and international trade of goods and services [1]. “If we don't change direction soon, we'll end up where we're heading" is the headline of the first paragraph in the executive summary of the World Energy Outlook 2011 [2]. It unfortunately represents systematic failure in combating climate change and the emphatic introduction of a "green society", leaving the fossil age behind. Certainly such far reaching transformations would take time, but recovery of the world economy since 2009, although uneven, again resulted in rising global primary energy demands [2]. It seems that more or less ambitious goals for climate change prevention are only resolved in phases of a relatively stable economy. Atmospheric carbon dioxide $\left(\mathrm{CO}_{2}\right)$ is the second most important greenhouse warming agent after water vapour, corresponding to $26 \%$ and $60 \%$ of radiative forcing, respectively [3]. Together with other greenhouse gases $\left(\mathrm{GHG}^{\prime}\right.$ ) $)$ (e.g. methane $\left(\mathrm{CH}_{4}\right)$, nitrous oxide $\left(\mathrm{N}_{2} \mathrm{O}\right)$ or ozone $\left(\mathrm{O}_{3}\right)$ ) they contribute to anthropogenic global warming. The industrialization has been driven by fossil sources of energy, emerging in the $17^{\text {th }}$ and $18^{\text {th }}$ century in England as a historical singularity, but soon spreading globally. 
Today, our economies still rely on relatively cheap sources of fossil energy, mainly crude oil and natural gas, and consequently emitting as much as 10 PG C per year in 2010 [4]. The Mauna Loa Observatory in Hawaii carries out the most comprehensive and longest continuous monitoring of atmospheric $\mathrm{CO}_{2}$ concentration. It publishes the well-known Keeling Curve, representing the dynamic change since 1958. Observing the Keeling Curve, one can easily recognize the seasonal variability which is directly triggered by $\mathrm{CO}_{2}$ uptake of vegetation (biomass) in the northern hemisphere during the vegetation period and secondly, which is even more important in terms of global change, a steady increase of $\mathrm{CO}_{2}$ concentration from 315 ppmv in 1958 to 394 ppmv in March 2012 [5]. Earlier concentrations could still be derived from air occluded in ice cores. Neftel et al. [6] presents accurate gas concentration measurements for the past two centuries. However, the theoretical knowledge of the warming potential of $\mathrm{CO}_{2}$ in the atmosphere evolved in the late $19^{\text {th }}$ century when a theory of climate change was proposed by Plass [7], pointing out the "influence of man's activities on climate" as well as the $\mathrm{CO}_{2}$ exchange between oceans and atmosphere and subsequent acidification. He highlighted the radiative flux controlled by $\mathrm{CO}_{2}$ in the 12 to 18 micron frequency interval, agreeing with a number of studies published in the forthcoming decades, e.g. Kiehl and Trenberth [3]. In order to understand the fate of anthropogenic $\mathrm{CO}_{2}$ emissions, research soon focussed on estimating sources and sinks as well as their stability, since it was obvious that the atmospheric concentrations did not rise at the same magnitude as emissions. Available numbers on current fluxes are principally based on the work of Canadell et al., [8] and Le Quéré et al., [1]. In their studies, it is emphasized that the efficiency of the sinks of anthropogenic $C$ is expected to decrease. Sink regions (of ocean and land) could have weakened, source regions could have intensified or sink regions could have transitioned to sources [8]. Another explanation might be the fact that the atmospheric $\mathrm{CO}_{2}$ concentration is increasing at a higher rate than the sequestration rate of sinks [1]. Moreover, $\mathrm{CO}_{2}$ fertilization on land is limited as the positive effect levels off and the carbonate concentration which buffers $\mathrm{CO}_{2}$ in the ocean steadily decreases according to Denman, K.L. et al. [1]. Fossil fuel combustion and land use change (LUC) are the major sources for anthropogenic C emissions (Figure 1). Land use change is usually associated with agricultural practices and intensified agriculture triggers deforestation in developing countries [9] and consequently causes additional emissions.

Another consideration is the availability of fossil fuel, which is limited by the fact that it is a non-renewable and therefore finite resource. Since the fossil energy system is based on globally traded sources with centralized structures, the vulnerability to disturbance is high. Recent examples of price fluctuations caused by political crises or other conflicts in producing countries or along transportation lines demonstrate potential risks. Moreover, a shift towards alternative energy sources and a decentralization of the energy system may contribute to system resilience and create domestic jobs. It prevents capital outflow to unstable political regimes and it helps to protect the environment not only by reducing GHG emissions, but also by reducing impacts of questionable methods of extracting fossil sources of energy (e.g. tar sands exploitation, fracking etc.). 

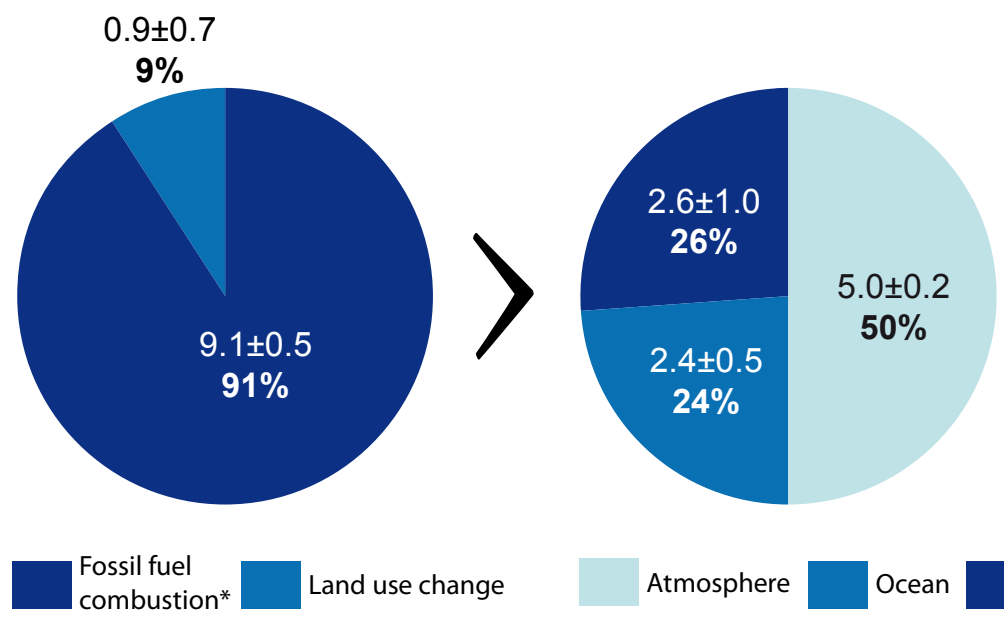

Atmosphere

Ocean

Terrestrial

Figure 1. The fate of anthropogenic $\mathrm{CO}_{2}$ emissions in 2010, showing sources (left) and sinks (right).

Presented numbers are Pg C yr-1. The values for 2010 were presented at the Planet under Pressure 2012 conference in London [4].

*includes cement production and flaring.

Biomass could play a significant role in the renewable energy mix. It is a feedstock for bioenergy production and currently thermal utilization (combustion) is by far the most important conversion process, but research activities are focussed on a range of different processes. This includes, for instance, the Fischer-Tropsch synthesis where any kind of biomass may be used as feedstock to produce liquid biofuels. This process is known as biomass - to - liquid (BtL). Research is pushed by national and international regulations (e.g. the EU's 2020 bioenergy target) and commitments, as a climate change mitigation strategy.

This chapter focuses on aspects of sustainable woody biomass production in Quercus dominated forest ecosystems with emphasis on different silvicultural management systems. Short rotation woody crops (SRWC), coppice with standards (CS), high forest (HF) and Satoyama are characterized according to their biomass potential and sustainability considerations. CS and HF are directly compared based on our own research and links to similar systems (SRWC and Satoyama) are drawn in order to provide a holistic view of the current topic. The chapter aims at providing an interdisciplinary view on biomass production in forest ecosystems, considering impacts on $\mathrm{C}$ and nutrient metabolism as well as other effects (e.g. biodiversity, technical, silvicultural and cultural issues). Considerations for sustainable biomass production in Quercus dominated forest ecosystems are presented for each management system.

\subsection{Biomass production and carbon sequestration}

Terrestrial $\mathrm{C}$ sequestration accounts for approximately one quarter of the three main sinks as indicated in Figure 2, where forests contribute the largest share. An intact terrestrial sink might be more important in the future in terms of mitigating climate change, since the ocean 
sink is expected to decrease. Our current forests are capable of sequestering $\sim 2.4 \mathrm{Pg} \mathrm{C} \mathrm{yr}^{-1}$ (of $2.6 \mathrm{Pg}$ in total), when excluding tropical land-use change areas [10]. Sequestration of $C$ in forests is controlled by environmental conditions, disturbance and management. However, forests can principally act as a source or sink of $\mathrm{C}$, depending on the balance between photosynthesis and respiration, decomposition, forest fire and harvesting operations. On both European and global scales, forests were estimated to act as sinks on average over the last few decades [11, 12].

The most important process of net primary production is achieved by photosynthesis, which is the chemical transformation of atmospheric $\mathrm{CO}_{2}$ and water from the soil matrix into more complex carbohydrates and long chain molecules to build up cellulose, which is found in cell walls of woody tissue as well as hemicellulose and lignin. The $C$ remains in the woody compound either until it is degraded by microorganisms, which use the $\mathrm{C}$ as source of energy, or until oxidation takes place (e.g. burning biomass, forest fire). In both cases, it becomes part of atmospheric $\mathrm{CO}_{2}$ again. A certain share, controlled mainly by climatic conditions [13], enters the soil pool as soil organic carbon (SOC). The ratio between aboveground and belowground pools depends on the current stand age, forest management and climate. In temperate managed forests, SOC stocks are typically similar to the aboveground stocks [14], which is confirmed in our own research [13]. SOC (and in particular O-horizon) stocks are typically higher in boreal forests and in high elevation coniferous forests as a consequence of reduced microbial activity and much lower in tropical environments. O-layer C pools are especially sensitive to changes in local climate. A traditional forest management regime in Austrian montane spruce forests is clear-cutting, typically from the top of a hill to the valley to facilitate cable skidding. An abrupt increase of radiative energy and water on the soil surface creates favourable conditions for soil microorganisms and a great amount of $\mathrm{C}$ stored in the O-layer will be released to the atmosphere by heterotrophic respiration. Other $\mathrm{GHG}^{\prime}$, such as $\mathrm{N}_{2} \mathrm{O}$ are eventually emitted under moist and reductive conditions as excess nitrogen is removed by lateral water flows. Unfortunately, this effect is likely to happen on a large-scale where massive amounts of C might be released as the global temperature rises and thawing permafrost induces $\mathrm{C}$ emissions [15], potentially creating a strong feedback cycle, further accelerating global warming. However, Don et al. [14] found that SOC pools were surprisingly stable after a major disturbance (wind throw event), indicating low short-term vulnerability of forest floor and upper mineral horizons. They explained their findings with herbaceous vegetation and harvest residues, taking over the role of litter $C$ input. The study covers a time-span of 3.5 years which might be too short to observe soil $C$ changes. Likewise, we did not observe significant $C$ stock decrease in our youngest sample plot of the coppice with standards (CS) chronosequence [13]. We expect that the $\mathrm{N}$ dynamics might have a profound influence on $\mathrm{C}$ retention and the impact of disturbance on SOC pools depends on environmental conditions. Successful long-term sequestration in terms of climate change mitigation is therefore only achieved if $\mathrm{C}$ becomes part of the recalcitrant fraction in the subsoil, which is typically between 1000 and 10000 years old [16, 17]. The C concentration is lower in the 
subsoil, but considerable amounts can still be found if one not only analyses the topsoil layer as recommended by a number of authors, e.g. by Diochon et al. [18]. In contrast, the radiocarbon age of the topsoil may range from less than a few decades [17] to months if considering freshly decomposed organic matter. The reasons for the relatively high age in subsoil horizons are not clear, but unfavourable conditions for soil microbial diversity and strong association of $\mathrm{C}$ with mineral surfaces (organo-mineral interactions with clay minerals) might be an explanation [16]. There are, in principal, two pathways for sequestering $\mathrm{C}$ in forest soils. Forest litter consists of leaves, needles and woody debris; such as branches, bark and fruit shells which accumulate on the surface (L and F layer). Soil macrofauna degrades it until it becomes part of the organic matter (OM) where it is impossible to recognize its original source (H layer). Parts of it are translocated into deeper horizons by bioturbation (e.g. earthworms) or remain on the surface, to be further degraded by soil microorganisms while organic matter becomes mobile in the form of humic acids and subsequently being mineralized at a range of negatively charged surfaces (humus, clay minerals). The second pathway is through root turnover and rhizodeposition (= excretion of root exudates). Matthews and Grogan [19] and subsequently Grogan and Matthews [20] parameterized their models with values of between 50 and $85 \%$ of $C$ from the fine root pool which is lost to the SOC pool on an annual basis, depending on species composition and management. This assumption is consistent with another study where $50 \%$ of the living fine roots were assumed to reflect real values [21]. There is evidence that $C$ derived from root biomass [22] and mycorrhizal hyphal turnover [23] might be the most important source for SOC pools rather than from litter decomposition. Since fine root turnover is species specific [24], it could be controlled to some extent by species composition at management unit levels. A further question for a forest owner in terms of carbon sequestration is which management option to choose while still being able to produce products and generate income. Despite the fact that unmanaged forests hold the highest $C$ pools, it was commonly believed that aggrading forests reach a maximum sequestration and it is reduced in old growth forests, where photosynthesis and autotrophic respiration are close to offsetting each other. This is contrasts a number of studies, pointing out that even unmanaged forests at a late successional development stage could still act as significant carbon sinks [25]. The authors of another study claim that advanced forests should not be neglected from the carbon sequestration discussion a priori [26] and they should be left intact since they will lose much of their $\mathrm{C}$ when disturbed [27]. Therefore, managing forests implies a trade-off between maximum $\mathrm{C}$ sequestration and provision of goods, such as timber and biomass for energetic utilization. While the highest amounts of carbon could be sequestered in unmanaged forests $[27,28], C$ sequestration through forest management can be a cost-effective way to reduce atmospheric $\mathrm{CO}_{2}$, despite limited quantities, due to biological limitations and societal constraints [29]. This is in general agreement with the conclusion of Wiseman's [30] dissertation, who argues that there is potential for additional $\mathrm{C}$ uptake depending on forest management, but the effect is short-term until a new equilibrium in $\mathrm{C}$ stocks is reached and also argues that the effect may be limited. 


\section{Biomass from forests}

There is an on-going debate regarding the potentials of obtaining biomass from forests on multiple scales, from stand to international levels. Biomass is often discussed in the context of a raw material for energetic utilization although it should be emphasized that total biomass figures account for the total harvestable amount of wood, regardless of its utilization or economic value. Especially in the context of energy, it is highlighted that biomass is an entirely $\mathrm{CO}_{2}$ neutral feedstock since the carbon stored in wood originates from the atmospheric $\mathrm{CO}_{2}$ pool and it was taken up during plant growth. This is, in principal, true despite biomass from forests not being free of $\mathrm{CO}_{2}$ emissions per se, since harvesting and further manipulation requires energy, which is currently provided by fossil fuels. However, it is difficult to estimate per-unit of $\mathrm{CO}_{2}$ emissions since there are many influential variables. Even a single variable could have a profound influence on the per-unit emissions as is shown for the case of chipped fuel [31]. In general, biomass requires a different treatment as compared to fossil sources of hydrocarbons. Chemical transformations over thousands of years under high pressure led to a higher density of yieldable energy per volume unit as compared to biomass, although hydrocarbons are ultimately a form of solar energy. Hence fossil infrastructure does not fit to sources of renewable energy because of intrinsic properties. Centralized structures of energy distribution might work for fossil fuels, but it is questionable if it makes sense to transport woodchips across large distances. The energy invested for (fossil based) transport eventually curbs the benefits of renewable energy resources in terms of $\mathrm{C}$ emissions. Biomass from forests to be used for energetic utilization in the context of conventional forestry is often seen as a by-product of silvicultural interventions and subsequent industrial processes. However, there are a number of woodland management systems focussing on woody biomass production for energetic utilization or a combination of traditional forestry and energy wood production. Table 1 compares a number of Quercus dominated woodland management systems and highlights the main differences and characteristics. These systems will be further described thereafter.

In conventional forestry (high forest), residues from thinning and subsequent product cycles; e.g. slash and sawdust; are seen as the most important feedstock for energy wood. This opens the floor for controversial discussions and assumptions, based in principal on ecological and economic concerns. While residues of thinning operations are requested by traditional industries (e.g. paper mills), the extraction of slash and other harvest residues eventually leads to nutrient depletion with ecological impacts and ultimately detriment to increments in the long-term perspective. Inherent climate and soil properties control both magnitude and duration of such developments. "Residues" from forestry were traditionally harvested in ancient times. Most of the raw materials extracted from forests served as a source for thermal energy (fuel wood and charcoal) or other feedstock for industrial processes. Moreover, forests in central Europe provided nutrients for agro systems to sustain the human population [32]. Forest pasture, litter raking and lopping (sometimes referred to as pollarding) are some examples. Extraction of nutrients is still a common practice, e.g. litter collection in the Satoyama woodlands of Japan [33]. Since all of these practices tend to extract compartments with a relatively high nutrient content in comparison to wood, soil acidification and nutrient 
depletion was a common threat in Central European forest ecosystems. Forests only recovered gradually, mainly because of acidic depositions starting from the beginning of industrialization until the late 1980's, when clear signs of forest dieback caused public awareness and subsequent installation of exhaust filters across Europe.

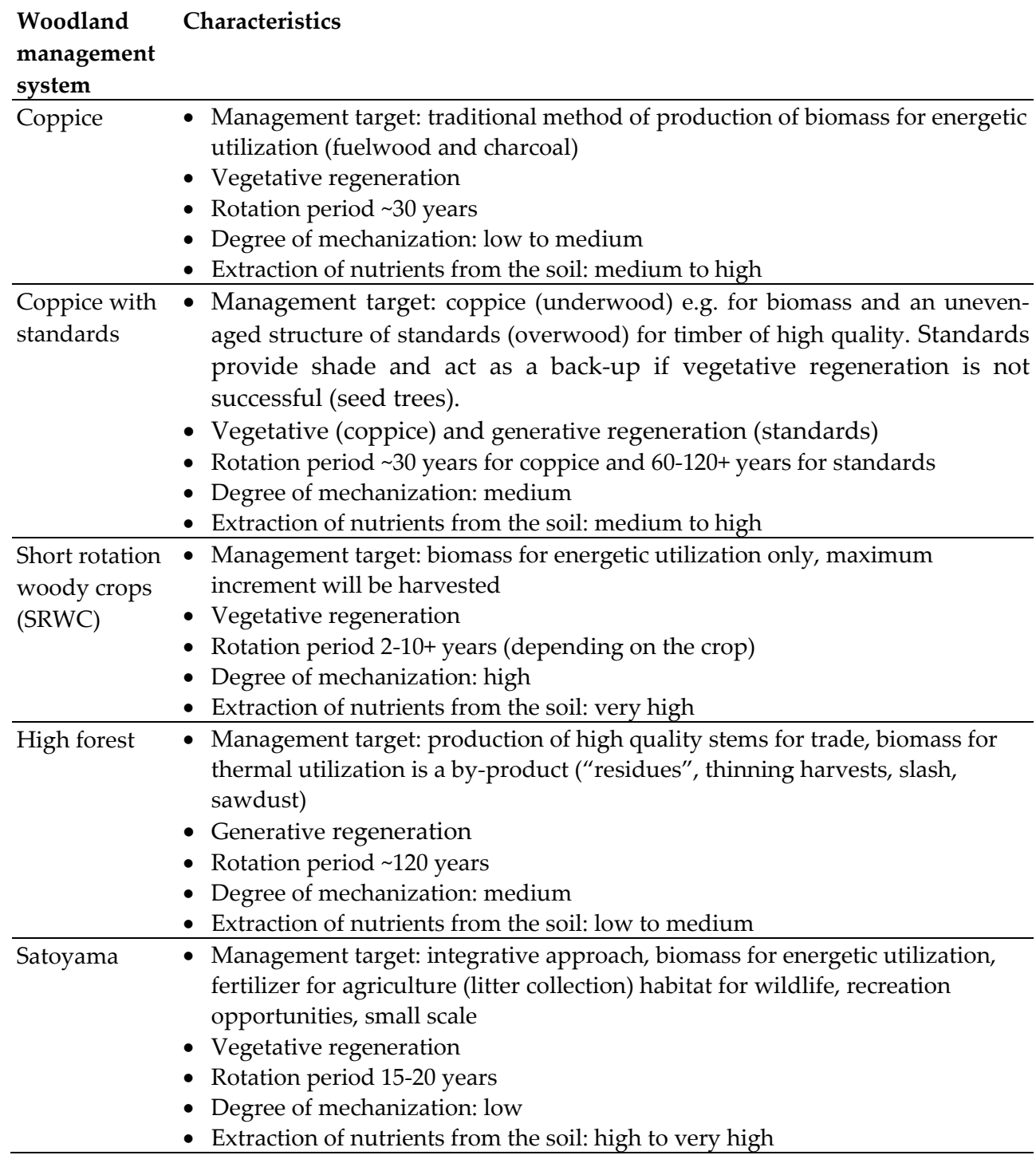

Table 1. Comparison of Quercus woodland management systems and their characteristics with regard to management target, regeneration, rotation period, degree of mechanization and nutrient extraction. Salix or Populus species are the dominating crop in Central Europe due to higher increment rates in SRWC as compared to Quercus species. 
Today, forest biomass stocks are increasing in most European countries, due to land use change (abandoned mountain pastures), shifting tree line as a consequence of global warming and elevated $\mathrm{CO}_{2}$ concentrations as well as atmospheric $\mathrm{N}$ deposition. However, this should not lead to short sighted assumptions that biomass can be harvested at levels of growth increment, since a large part of it grows in areas with unsuitable conditions for access. Easily accessible forests at highly productive sites in lowlands are already typically managed at harvesting rates close to increment or even higher, e.g. in cases of natural disasters such as wind throws. In some countries, such as Austria, access to specific land ownership structures might uncover greater potentials of additional harvests.

\section{Short rotation woody crops (SRWC) - A model of agriculture in forestry business}

The major challenges of shifting forest management goals from traditional forestry to biomass production are sustainability issues, relatively low value of the product in comparison to quality logs and expensive harvesting, being competitive only at a high degree of mechanization in developed nations. As a consequence, rotation periods were shortened and fast growing species are preferred in order to produce woody biomass in an agriculture-like manner. Since the increment is highest at the beginning of stand development and subsequently decreases, only the maximum increment is utilized, ensuring maximum biomass production capacities at a given site. Short-rotation woody crops (SRWC) are hence established, in Europe typically with fast growing willow (Salix) or poplar (Populus) species. However, fast growing hardwood Quercus species are also considered for short rotation [34]. SRWC originated in ancient times, when people coppiced woodlands in order to obtain raw materials, e.g. fuel wood for cooking or heating purposes, but most of the research has been carried out and application of the results has been achieved in the last 50 years [35]. The basic principles of SRWC therefore originate in a coppice land management system, which will be described below. Planting is optimized for maximum biomass production (increment) while minimizing threats of disease and facilitating highly mechanized harvest technologies. Typical rotation periods are between 1 and 15 years [35], and rotations of Salix are shorter ( $<5$ years) than those of Populus and Quercus. Biomass from short rotations extracts significant amounts of soil nutrients, since a higher share of nutrient rich compartments (bark and thin branches) is extracted from the system. In combination with the short rotation cycles, nutrient extraction rates are larger as compared to conventional forestry. This implies the need of fertilization in most cases and concerns, e.g. about $\mathrm{N}$ leaching into groundwater bodies are discussed. However, Aronsson et al.[36] showed that high rates of $\mathrm{N}$ fertilization do not necessarily prime leaching, even on sandy soils (Eutric Arenosol) if the demand for $\mathrm{N}$ is high. $\mathrm{C}$ sequestration in the soil is also primarily controlled by $\mathrm{N}$ fertilization and the response of the vegetation [37]. The authors found increasing biomass production and $\mathrm{C}$ sequestration in a hybrid poplar plantation following $\mathrm{N}$ fertilization. On the other hand, it was argued that short rotations eventually result in the loss of the mineralization phase, thus preventing self-regeneration of the forest ecosystem [38]. Following their argument, a rotation cycle should be long enough to permit 
the return of autotrophic respiration and high rates of mineralization. In terms of $\mathrm{C}$ sequestration potential, it ultimately depends on the land use prior to SRWC if and to what extent additional $\mathrm{C}$ is accumulated. Especially sites that were formerly used for agricultural purposes and where organic carbon was depleted are prone to additional sequestration after land conversion [19, 20]. They pointed out that especially, but not only, non-woody Miscanthus plantations, can substantially sequester $\mathrm{C}$ with relative high amounts of litter. In a global context, SRWC may interfere with agricultural production if it continues to be a focus and if plantation areas increase since most plantations are not the result of forestland conversion, but rather farmland conversion. One of the reasons for this interference is the varying legal definition of SRWC across nations. While SWRC is considered forest in some countries, it is treated as an agricultural crop in other nations, making comparisons and predictions across borders difficult.

\section{Coppice with standards and high forest management in Austria}

High forest (HF) and Coppice with standards (CS) are the most common silvicultural management systems for broadleaved forest ecosystems in northeastern Austria. These systems have evolved over a long period of traditional management and they are mainly determined by environmental conditions and economic considerations. However, these systems were locally adapted over time, resulting in a range of intermediate types. Divergent silvicultural structures with diffuse standards are the consequence and are very common in Austria [39].

Quercus dominated high forests aim at producing quality timber with a diameter of at least $30 \mathrm{~cm}$ (diameter at breast height $(\mathrm{DBH})$ ). Rotation periods are approximately 120 years, followed by shelterwood cuts and natural regeneration. It is one of the most common systems in central Europe and suitable for most species. The rotation period is set according to the dominant or most economically significant species and it is usually shorter for coniferous species ( 100 years). The most important difference in comparison to other management systems is the type of regeneration, which in the case of high forest is entirely generative. Generative regeneration may be introduced by shelterwood cuts or similar silvicultural systems, or by planting, while natural regeneration is usually preferred as a consequence of costs and genetic compatibility issues (e.g. climate) and uncertain provenance. Shelterwood cuts promote generative regeneration via seeds when the canopy is opened. Individuals with high quality (i.e. straight stem) may be chosen to initiate regeneration, which implies genetic selection to a certain extent. Thinning is typically performed 4 times, at 30, 50, 70 and 90 years. The main silvicultural goal is to produce straight logs with a minimum number and size of ingrown branches, as a raw material for woodwork, veneer and other similar purposes. Thinning operations and harvesting residues provide biomass for energetic utilization. Individual generative stems might be considered as a source of woody biomass for energetic utilization as well, if they do not meet requirements in terms of quality.

Quercus-Carpinus coppice with standards is a woodland management system to produce biomass for energetic utilization. These forests were once the main source of thermal energy 
when producing fuelwood for direct burning or charcoal production. There is evidence of coppice management dating back approximately 400 years in this region of Austria [40]. The management goals shifted during this period, depending on the demands of the landowners. CS is a relatively flexible system regarding supply of different qualities and quantities of wood. Among coppice, some trees are left in four age-classes to grow as larger size timber, called "standards". While standards provide a certain share of higher quality logs for trades, coppice provides fuelwood. Standards typically result from genetic regeneration. This multi-aged traditional system supports sustainable production of timber and non-timber forest products, while enhancing ecosystem diversity and wildlife habitat [41], which is also highlighted in the similar Japanese management system of Satoyama [33]. The rotation period for coppice (understorey) is typically 30 years [39, 42], hence holding a middle position between planted short rotation woody crops (SRWC) [35] and traditional high forests. The system is characterized by cyclic vegetative and generative regeneration [42]. Sprouting occurs rapidly after harvest and standards provide shade and are a source for seeds as backup if sprouting is not successful. Individual standards are managed in four age classes (30-60, 60-90, 90-120, and 120+ years) and harvested depending on certain criteria (e.g. market value, tree health, stand density). However, their importance began to cease with the introduction of fossil sources of energy during the onset industrialization, but significantly after 1960 [39]. Declining fuelwood demands led to a reduced intensity of understorey harvests (coppicing) and a shift towards longer rotation periods. This trend is especially distinct on fertile sites, while coppice was tendentially retained on sites with lower fertility.

The parent material of soils in our study region consists of gravel, sand and silt built up during the Pannonium (between 7.2 and 11.6 Ma before present) resulting from early formation of the Danube River. Consequently, a variety of soils can be found, e.g. Cambisols, Luvisols, Chernozems and even Stagnosols. Younger aeolian deposits of loess (Pleistocene) led to periglacial formation of Chernozems. The soils of our chronosequence series are classified as Eutric Cambisol with a considerable amount of coarse material $(\leq 40 \%$ volume) in HF and sandy clay loam texture and both Haplic and Vermic Chernozems with loamy texture in CS [43]. Soils with lower fertility are derived from gravel and sand of the Danube River development, while Chernozems are derived from loess. The region receives approximately $500 \mathrm{~mm}$ of precipitation annually, with irregular periods of drought during summer. The water holding capacity of soils with a considerable amount of coarse material is lower as compared to loess derived soils, hence vegetative regeneration has the advantage of a fully functional root system at all times, supporting successful regeneration even in periods of drought. Generative regeneration might be obstructed under such conditions as a consequence of drying topsoil horizons. In our case study, we were able to include an outgrown coppice plot (i.e. a coppice with standards system that was not harvested at the theoretical end of the rotation period) aged 50 years to widen the scope for temporal dynamics. Irregular harvesting of standards and rotation periods up to 50 years (outgrown coppice) led to divergent silvicultural structures with diffuse standards [39], as previously mentioned. The plots were established during the summer of 2007 as permanent sample plots for aboveground biomass monitoring and are part of a framework to investigate biomass and carbon pools in this region [44]. 


\subsection{Research methods}

Studying temporal aspects of stand development is challenging because of the inherent duration of rotational cycles. Even in the case of CS in our example, it is theoretically 30 years but we included a 50-year-old outgrown stand. In HF, the rotational cycle is twice as long. Pickett [45] recommended a false chronosequence approach where he substitutes time for space. It is therefore crucial to find stands with similar management, species composition and other environmental conditions (microclimate, soil, topography), only differing in stand age. It must be assumed that the stands follow convergent succession trajectories [46], which was ensured in our case by use of inventory data from the past. The chronosequence approach is generally contested since it comes with a set of limitations (e.g. the problem of regional averaging, ignoring major disturbances or site-specific parameters as well as variation between hypothetical stands at the same age). Moreover, it assumes that there are no major disturbances (e.g. windthrows, insect attacks) during the rotational cycle. However, the method allows a researcher to successfully study temporal changes through the judicious use of chronosequences [46] and is often the only possible method to study long-term dynamics. Five plots were chosen for each chronosequence in HF and CS, ranging from 1-50 years in CS and 11-91 years in HF, respectively (Table 1).

A full biomass inventory was performed above- and belowground using allometric functions from Hochbichler [42]. In addition, belowground fine root biomass was determined to a depth of $50 \mathrm{~cm}$ by using soil cores. Additionally, soil macronutrient analysis was performed using these samples. Details for plot selection and setup as well as investigation of compartments and subsequent laboratory methods can be derived from Bruckman et al.[13]. The HF forest was chosen for comprehensive soil analysis, including exchangeable cations in soil and nutrient pools of different aboveground compartments, such as foliage, bark, wood and branches as well as regeneration and stems (see Figure 3). Exchangeable cations were determined at different soil horizons by using a $\mathrm{BaCl}_{2}$ extraction and subsequent Inductively Coupled Plasma - Optical Emission Spectroscopy (ICP-OES) analysis. Exchangeable phosphorus pools were estimated using data from the forest soil inventory of adjacent forest sites [47]. Macronutrients N, P and K were determined in biomass compartments (foliage, bark of stems $>8 \mathrm{~cm}$ diameter, wood of stems $>8 \mathrm{~cm}$ diameter, composite sample of stems $<8 \mathrm{~cm}$, branches $>2 \mathrm{~cm}$ diameter, branches $<2 \mathrm{~cm}$ diameter and regeneration $<1.3 \mathrm{~m}$ height) according to inventory data for the most abundant species at each forest site. Nutrient analysis is based on three full tree samples (aboveground compartments) for Quercus and three foliage and branch samples from different crown layers per plot and species. Foliage was collected in August 2011 to ensure sampling fully developed leaves. $\mathrm{HNO}_{3} / \mathrm{HClO}_{4}$ extraction according to ÖN L 1085 [48] followed by ICP-OES analysis was used to determine nutrient contents.

\subsection{Aboveground biomass}

Aboveground biomass pools increased with stand age in both forest management systems as a consequence of steady accumulation (Figure 4). HF follows a typical pattern with high increments in the aggregation phase and marginal accumulation rates after 50 years. 
Thinning concentrates additional growth on selected individuals with the highest possible quality, while low quality stems are harvested and utilized as fuelwood or further chipped. Hence the silvicultural activities aim at refining the product instead of maximizing biomass production. Approximately $2 / 3$ of the aboveground biomass corresponds to understorey in the youngest HF site (11 years), while its share decreases steadily with increasing stand age (Table 1). The slightly rising share in the oldest stand (from $\sim 3$ to $\sim 5$ ) could be explained by initiation of generative regeneration as the canopy opens after thinning operations, allowing seeds to germinate and initiate regeneration.

\begin{tabular}{lllllll} 
Site & $\begin{array}{l}\text { Age } \\
\text { [years] }\end{array}$ & \multicolumn{2}{c}{ Biomass stocks [t/ha $\mathbf{~}^{-1}$ dry mass] } & \multicolumn{2}{c}{ Biomass stocks [\%] } \\
\cline { 3 - 7 } & Overstorey & Understorey & Sum & Overstorey & Understorey \\
\hline HF1 & 11 & 9.8 & 4.9 & 14.7 & 33.3 & 66.7 \\
HF2 & 32 & 81 & 18.1 & 99.1 & 81.7 & 18.3 \\
HF3 & 50 & 111.9 & 13.9 & 125.8 & 88.9 & 11.1 \\
HF4 & 74 & 137.4 & 4.1 & 141.5 & 97.1 & 2.9 \\
HF5 & 91 & 130.3 & 7.1 & 137.4 & 94.8 & 5.2 \\
\hline CS1 & 1 & 133.2 & 0 & 133.2 & 100 & 0 \\
CS2 & 15 & 73.8 & 31 & 104.8 & 70.4 & 29.6 \\
CS3 & 26 & 147.7 & 36.7 & 184.4 & 80.1 & 19.9 \\
CS4 & 31 & 138.7 & 65 & 203.7 & 68.1 & 31.9 \\
CS5 & 50 & 167.5 & 87.5 & 255 & 65.7 & 34.3 \\
\hline
\end{tabular}

Table 2. Aboveground biomass stocks in tons per ha-1 dry mass for HF and CS, separated into overstorey and understorey compartments. In HF, overstorey represents individuals with $\mathrm{DBH}>8 \mathrm{~cm}$, while understorey represents individuals with $\mathrm{DBH}<8 \mathrm{~cm}$ respectively. In $\mathrm{CS}$, overstorey represents standards and understorey the vegetative coppice regeneration with some individuals being the result of generative regeneration.

In CS, we found a steady increase until the end of the rotation as the stand is still in the aggradation phase. The 15 year old stand is an exception because standards were previously harvested (irregular cut) resulting in lower biomass stocks as compared to the one year old stand where the total biomass equals that of standards. The relationship between overstorey and understorey biomass stocks is typical for coppice with standards forest management. While the overstorey stocks remain relatively constant (between 133 and 168 t.ha $^{-1}$ ), except in the 11 year old CS site where standards were recently harvested, the understorey coppice biomass pool constantly increases to 88 t.ha $^{-1}$ at an age of 50 years (see Table 1). The relative share of coppice biomass increases from $20 \%$ in a 26 -year-old stand to $34 \%$ in the oldest stand. This is an example for adaptive forest management since the demand for fuelwood has been low for decades and we were consequently able to find outgrown CS plots (50 years) and the share of coppice biomass is still relatively low. It could be increased under a different demand structure, where biomass for energetic utilization is in demand and commercialization becomes an interesting option for the forest owner. 


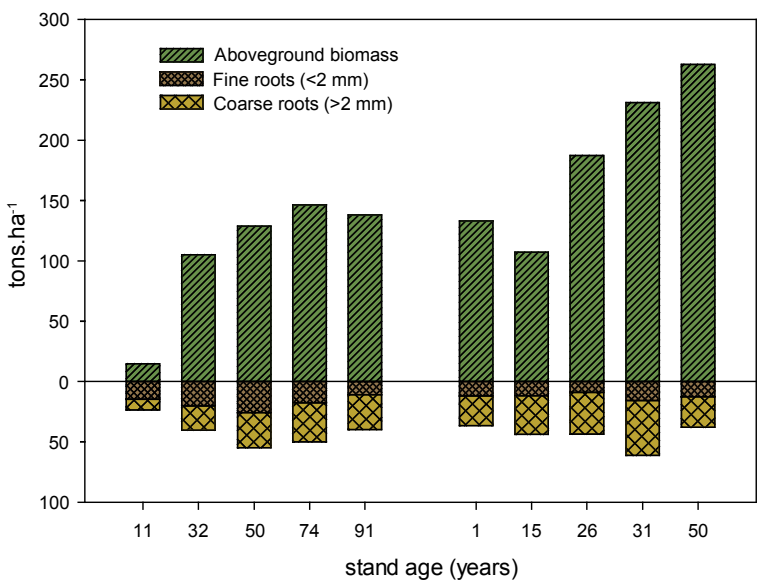

Figure 2. Aboveground (shoot) and belowground (root) biomass (dry mass) in two different forest management systems (high forest and coppice with standards). Data from Bruckman et al. [13].

On average, approximately $40 \%$ less biomass is stored in the HF system aboveground, and $7 \%$ less belowground (roots). Net primary production (NPP) is higher in CS which compensates lower basal area of the overstorey $(\mathrm{DBH}>8 \mathrm{~cm})$ with higher stand density [13]. The main reason of elevated NPP in CS is the higher fertility of chernozems as compared to cambisols in combination with a more effective water holding capacity as compared to the Eutric Cambisol in HF as a consequence of the coarse material content. The underlying silvicultural practices contribute to this biomass pool structure as thinning is performed at regular intervals in HF while typically only one intervention takes place in CS when harvesting coppice and selected standards at the end of the rotational cycle. As a consequence, additional C sequestration may only be achieved in CS when extending the rotation period. The second argument leads to higher productivity of the CS system, which allows higher $\mathrm{C}$ sequestration rates.

\subsection{Belowground biomass}

As previously mentioned, fine root turnover might be the most important pathway of $\mathrm{C}$ sequestration in forest ecosystems. Therefore, it is crucial to study root dynamics and turnover in the context of forest management. Our case study confirms that on average, fine root biomass (FRB) decreased with increasing stand age in HF $(R=-0.28 ; p<0.01)$ but remained constant in CS. This basically reflects aboveground biomass dynamics where the CS system has a relatively balanced stand structure throughout rotational cycles. It is partly a consequence of shorter rotation cycles and therefore retains the aggradation phase [49]. Another reason lays in the continuous growing stock, since standards are kept on site during and after understorey harvest. Considering a finer resolution one may observe dynamic changes in FRB corresponding to stand development stages. FRB increased after stand reorganization, culminated at an age of 31 (CS) and 50 years (HF) and subsequently decreased as stands aged. In accordance with increasing aboveground biomass stores, 
coarse root $C$ pools increased with age in HF ( $R=0.87$; $p=0.53)$, accounting for $8.0(0.9) \%$ of total $\mathrm{C}$ pool and no trend was observed in CS, where coarse root $\mathrm{C}$ pools accounted for 7.8 (1.0) \% respectively [13]. Although on average HF has lower total belowground biomass stores (7 \% less), the FRB is 32\% higher as compared to CS. The root-to-shoot ratio indicates higher belowground relative to aboveground biomass accumulation rates in early successional phases. A direct comparison between HF and CS reveals two major differences:

1. In comparison with HF, there was no initial major decrease of the ratio observed in CS

2. The ratio is always lower in CS than in HF

These differences may be due to significant aboveground biomass stocks represented by standards in CS and therefore comparatively low ratios, even in the stand reorganization phase. Consequently, root/shoot ratios are in equilibrium throughout the rotation period. More favourable soil conditions in CS may lead to lower ratios throughout stand development. It was shown that drought and limited soil resources (nutrient) availability promote FRB production [50,51]. The effect of standards harvesting was observed in our case study as a slightly higher ratio in the 15-year old stand compared with the one-year old stand in CS. On average, the root C pool represented $28.0(3.0) \%$ of total phytomass C stores when excluding the youngest HF stand where the root $C$ pool was 1.6 times as high as aboveground phytomass stores [13].

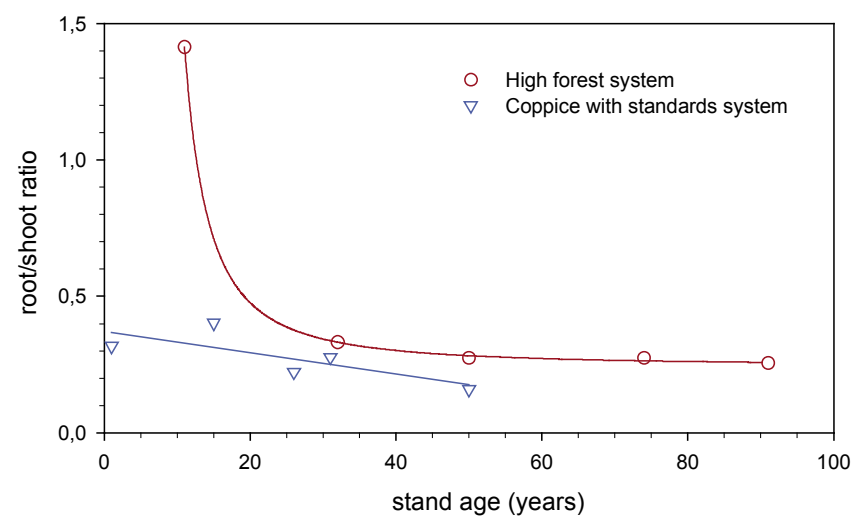

Figure 3. Root/shoot ratios of High forest system (HF) and Coppice with standards system (CS). The solid lines represent a hypothetic pattern. Source: Bruckman et al. [13].

\subsection{Nutrient analysis}

A comprehensive elemental analysis was performed for the HF system in both soil horizons and biomass compartments in the context of the framework for biomass investigations in northeastern Austria. HF was chosen because of lower soil fertility in comparison to the CS sites, which implies a higher sensitivity with regard to nutrient extraction.

The nutrient balance at a given site is an essential factor for stand productivity, species composition and biodiversity. Gains of nutrients that are in plant available forms and 
therefore could be incorporated in new plant tissue are limited to originate from weathering of bedrock material, atmospheric deposition as well as fertilization. The major processes of decreasing nutrient availability to plants are removal (biomass extraction and leaching) or chemical transformation processes, resulting in recalcitrant and thus plant unavailable fractions. Soil microbes play an important role in these processes and there is even a competition for some elements, e.g. $\mathrm{N}$ between microbes and plant roots [52]. Interfering nutrient cycles, e.g. by changing forest management practices therefore influences a complex system. The consequences are not usually recognized immediately, depending on the nutritional status of the soil. If nutrient pools and cation exchange capacity (CEC) are low, the consequences are seen within just a few years, as is the case in tropical soils, for instance.
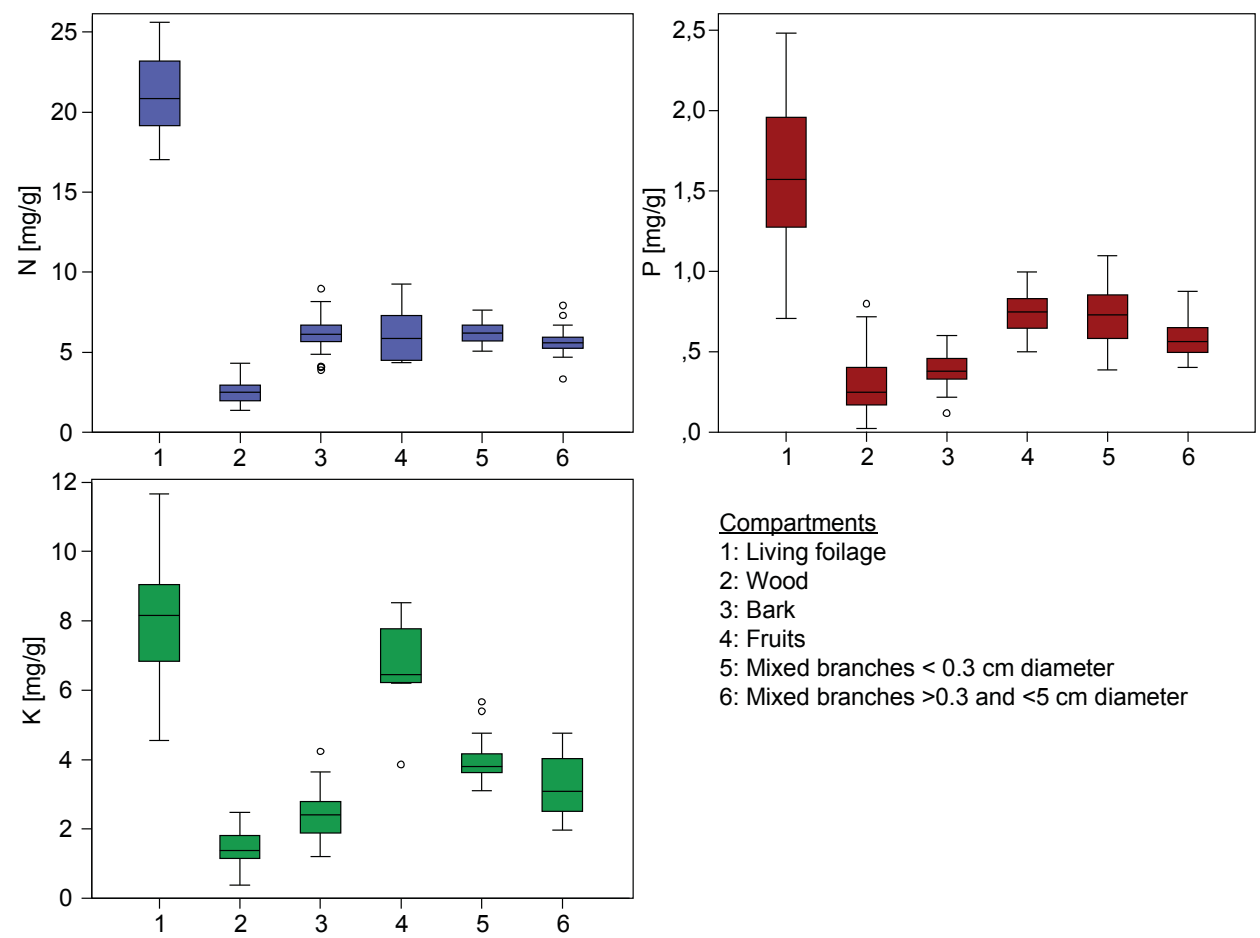

\section{Compartments}

1: Living foilage

2: Wood

3: Bark

4: Fruits

5: Mixed branches $<0.3 \mathrm{~cm}$ diameter

6: Mixed branches $>0.3$ and $<5 \mathrm{~cm}$ diameter

Figure 4. Nitrogen $(\mathrm{N})$, Phosphorous $(\mathrm{P})$ and Potassium $(\mathrm{K})$ content in $\mathrm{mg} / \mathrm{g}$ dry mass of different compartments for the dominating species, Quercus petraea in the HF system. Note that foliage is the compartment with the highest content of all macronutrients. Boxplots show the median (solid horizontal line), the bottom and the top of the box represent the $25^{\text {th }}$ and the $75^{\text {th }}$ percentile (interquartile range) and the whiskers show the highest and lowest values that are not outliers $(<1.5$ times the interquartile range).

Based on an analysis of nutrient contents in various compartments (Figure 5), the aim was to compare plant available (exchangeable) pools of nutrient elements in soil with aboveground pools. This was done in order to determine potential nutritional bottlenecks when the management goal shifts towards biomass production as a source for energy, which implies 
higher nutrient extraction rates as compared to conventional forestry or intermediate types (see Table 1). We focussed on the dominant tree species (Quercus petraea, Carpinus betulus and Corylus avellana) where we sampled whole trees on each plot to account for local differences. Only foliage and branches were sampled from less abundant species (e.g. Fagus sylvatica, Betula pendula and Prunus avium) where they occurred.
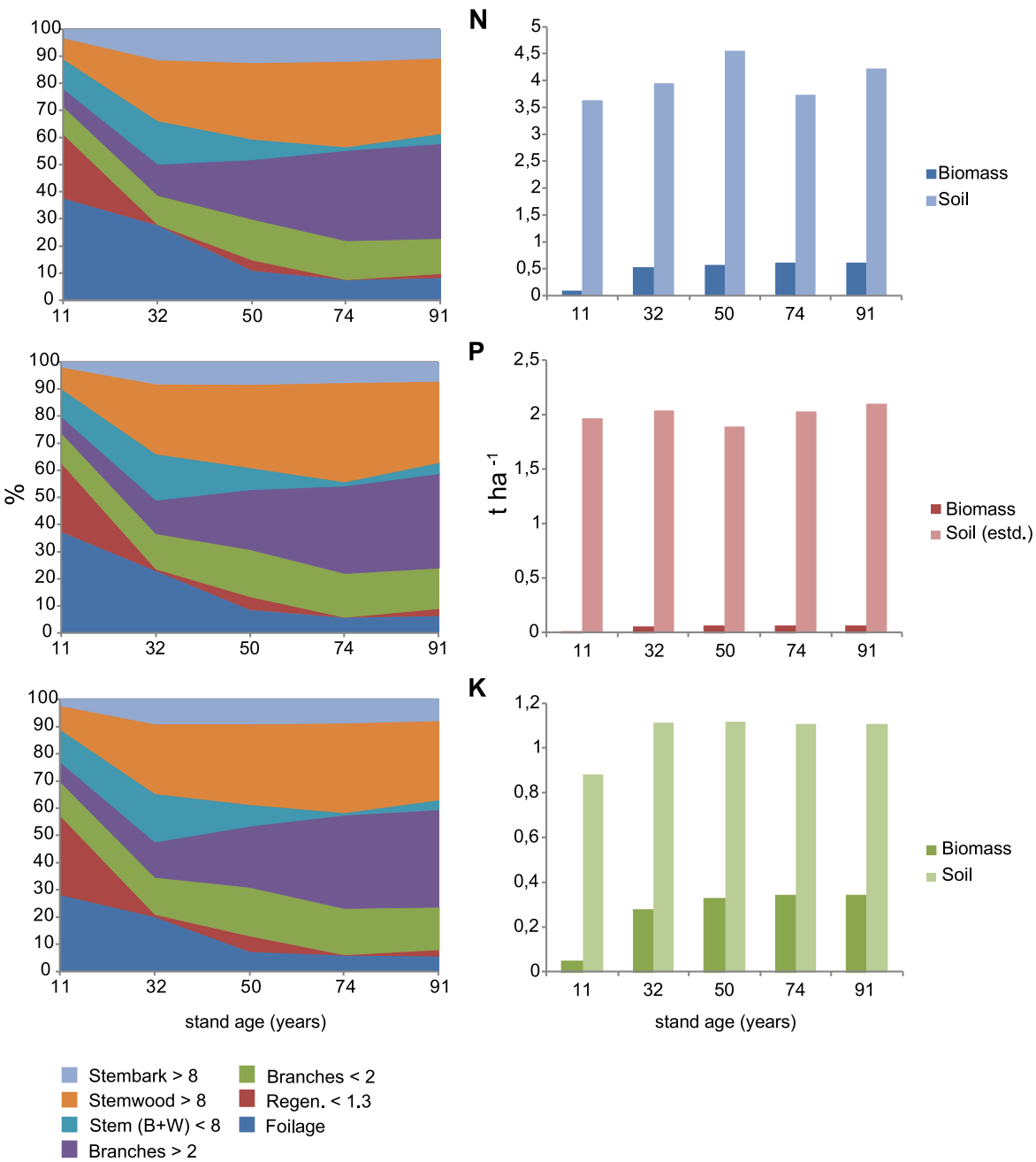

K

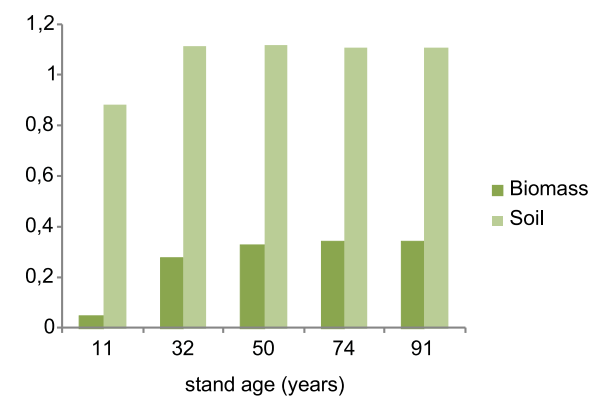

Figure 5. Relative amount of macronutrients in different compartments of Quercus petraea along the HF chronosequence (left) and a comparison of macronutrient contents in aboveground biomass and exchangeable soil pool (right). Category explanation (same order as legend): Bark of stems $>8 \mathrm{~cm} \mathrm{DBH,}$ stemwood excluding bark of stems $>8 \mathrm{~cm} \mathrm{DBH}$, stems $<8 \mathrm{~cm} \mathrm{DBH} \mathrm{(wood} \mathrm{and} \mathrm{bark),} \mathrm{branches}>2 \mathrm{~cm}$ diameter (wood and bark), branches $<2 \mathrm{~cm}$ diameter (wood and bark), regeneration $<1.3 \mathrm{~m}$ height (total value), foliage (living). Soil exchangeable P pools were not actually measured, but estimated from data of the Austrian forest soil inventory [47]. 
Figure 5 illustrates the macronutrients nitrogen, phosphorous and potassium (NPK) contents of different compartments. Foliage clearly has the highest contents of macronutrients, followed by bark and thin branches. In the 91-year-old stand, foliage only accounts for $1.7 \%$ of the aboveground biomass, but represents $8.2 \%$ of the $\mathrm{N}$ pool, while $23.3 \%$ represent $37.5 \%$ in the youngest stand respectively. Wood (sapwood and heartwood) had the lowest contents. Similar patterns of nutrient distribution were previously reported for the same species [53]. The nutrient content of composite samples (wood and bark) depends on the respective proportions of wood and bark. However, it seems different for the case of $\mathrm{P}$ where higher contents in the composite as compared to separate wood and bark samples indicate higher contents of $\mathrm{P}$ in bark of thin branches (Figure 5). The bark sample consists of bark from branches and stem where the latter is therefore expected to have lower P contents. Approximately $40 \%$ of the macronutrients are stored in stems $>8 \mathrm{~cm}$ in diameter from an age of 50 years onwards (Figure 6) while representing approximately $60 \%$ of the stand aboveground biomass. Bark accounts for another $10 \%$ of the $40 \%$ stem pools. Consequently it was suggested to consider oak stem debarking to limit nutrient exports (especially Ca in the case of Quercus bark) from the stand [53]. A comparison with exchangeable soil pools revealed sufficient potential supplies from the soil matrix as the soil pools of macronutrients are well above the stand biomass pools. However, a simple comparison of pools does not necessarily represent the nutritional status of the vegetation since plant availability, stress and soil biogeochemical processes may cause uptake limitations of certain nutrients. For instance, the N:P ratio is well acknowledged as an indicator for either $\mathrm{N}$ or $\mathrm{P}$ limitation and values of $<14$ indicate $\mathrm{N}$ deficiency where values of $>16$ designate $\mathrm{P}$ limitation [54]. Obviously pools of soil exchangeable $\mathrm{P}$ are very high (Figure 6) which is also represented in our foliar N:P ratios. They are very stable at 14.2 for the 50, 74 and 91 year old stands and close to the threshold value (13.9) in the 32 year old stand. Interestingly the youngest stand (11 years) shows signs of $\mathrm{N}$ limitation with a ratio of 10.3. We suggest a combination of reasons for this observation. High rates of increment have a great $\mathrm{N}$ demand in the stand organization and subsequent aggradation phase. Herbaceous vegetation on this specific site might compete with woody species for topsoil $\mathrm{N}$ and the relatively high coarse material content contributes to low water holding capacities. In combination with low rates of precipitation, water availability might inhibit mobilisation and uptake of $\mathrm{N}$ at this site as suggested in a comprehensive review [34]. It is also shown that although the forest is surrounded by intensively managed agricultural land with associated atmospheric deposition of aerosols (dust), it has not led to P limitation as recently suggested [54]. In summary, despite evidence for $\mathrm{N}$ limits in the youngest stand, the macronutrient supply meets the demand under current forest management. However, it could be problematic if lower diameter compartments are extracted as biomass for energetic utilization. For instance, if the crown biomass is utilized at the final harvest and branches with a diameter $>2 \mathrm{~cm}$ are being extracted, it will account for a twofold extraction of $\mathrm{N}$ as compared to stem-only harvests. In a scenario of whole tree harvesting, close to $90 \%$ of $\mathrm{N}$ in biomass will be extracted, compared to approximately $40 \%$ in the stem-only scenario. Stem debarking could further reduce $\mathrm{N}$ extraction to below $30 \%$ of the total aboveground biomass pool. This example demonstrates the importance of assessing the dynamic nutrient pools in 
order to provide profound recommendations for sustainable forest management, as was concluded in a previous study [53]. Forest nutrition not only has implications on species diversity, sequestration of carbon, and provision for a magnitude of environmental services, but it has distinct implications on site productivity and thus earning capacity of a given management unit. Sustainable nutrient management is therefore an essential component of successful forest management, especially if management aims at harvests that are more intensive for bioenergy production.

\section{Sustainable coppice biomass production: the Japanese example of Satoyama}

Satoyama forests have a long tradition in Japan. Directly translated "sato" means "village" and "yama" "mountain" [55]. The translation points at the conceptual meaning of Satoyama, which describes the typical landscape between villages and mountains (Okuyama). Although there are many definitions, one probably finds a suitable one in the Daijirin dictionary: "the woods close to the village which was a source of such resources as fuelwood and edible wild plants, and with which people traditionally had a high level of interaction" [56]. Satoyama could be understood as an integrative approach of landscape management, including the provision of raw materials such as wood, natural fertilizer (see the transfer from nutrients from forests to agricultural systems as previously mentioned), drinking water and recreational opportunities. Besides its inherent economic and ecological values, it provides a sphere for human-nature interactions and as such, it opens a window to see how Japanese perceive and value their natural environment over time [56]. As a consequence of small-scale structures and specific management, Satoyama woodlands represent hotspots of biodiversity [55]. They are pegged into a landscape of paddy fields, streams and villages. From a silvicultural point of view, Satoyama woodlands consist of mainly deciduous species, such as Quercus acutissima and Quercus serrata (however, Japanese cedar is sometimes used to delimit parcels of different ownership), which are coppiced on rotational cycles of 15-20 years, creating a mosaic of age classes [33]. Along with their scenic beauty and recreational capabilities which is doubtlessly a strong asset close to urban megacities, Satoyama woodlands are capable of providing goods and services for the society; even under conditions of changing demands and specific needs of generations [57]. In contrast to Satoyama, coppice forests in Austria were traditionally managed to obtain fuelwood and because of suitable environmental conditions for coppicing. Low levels of precipitation $\left(\sim 500 \mathrm{~mm} \mathrm{yr}^{-1}\right)$ promote coppicing, since a fully established root system is present at any time, stimulating re-sprouting even under periods of drought. However, the holistic approach of landscape management is by far not considered to the same extent as it is for Satoyama. The importance of coppice forests for biomass provision ceased with the utilization of fossil fuels. Likewise, Satoyama was devaluated as a result of the "fuel revolution" in Japan [57], during which large areas were abandoned, leading to dismissed or poorly managed Satoyama woodlands. This is comparable with the previously mentioned divergent silvicultural structures with diffuse standards in Austria [39]. Satoyama woodlands are now back in the public interest, starting in the 1980s when volunteer groups 
formed, being part of the Satoyama movement which urged for development of adequate environmental policies [33]. Although most groups are focussed on recreational activities in urban and peri-urban areas, the potential of Satoyama to provide biomass for energetic utilization has recently gained attention. Terada et al. [33] calculated a $\mathrm{C}$ reduction potential of $1.77 \mathrm{t} \mathrm{ha}^{-1} \mathrm{yr}^{-1}$ of $\mathrm{C}$ for the Satoyama woodlands if coppiced and the biomass is utilized in $\mathrm{CHP}$ power plants. Considering the total study area (including settlements, agricultural areas and infrastructure, the $C$ reduction potential is still $0.24 \mathrm{t} \mathrm{ha}^{-1} \mathrm{yr}^{-1}$. In the context of nutrient budgets, practices such as cyclic litter removal have to be evaluated with regard to the base cation removal rates and subsequent acidification, which ultimately leads to lower ecosystem productivity as was previously shown. Litter removal may cause substantial nutrient extractions of the compartment with the highest contents (Figure 5). The Fukushima Daiichi nuclear incident clearly showed the threat of nuclear fission energy sources. In combination with efforts to cut carbon emissions, paired with rising demands for energy, the situation caused a shift towards sustainable, clean and safe forms of energy provision. If a sustainable management is applied, especially in the context of nutrient budgets, Satoyama perfectly fulfils these requirements and might be a good choice to include in the future energy system while being neutral in terms of GHG release. Satoyama could represent a good model for sustainable resource management that the rest of the world can learn from $[55,56]$. A study to evaluate Satoyama landscapes on a global basis was started under the "Satoyama initiative", launched by the Japanese Ministry of the Environment".

\section{Conclusion}

Specific types of biomass, i.e. wood and wood-derived fuels, have a long history of being the major source of thermal energy since humanity learned to control fire, which was a turning point in human development. These sources have not lost their significance in many developing countries, especially in domestic settings. However, over-population, climatic conditions and low efficiency cause shortages of fuelwood in many regions, e.g. Ethiopia or Northern India. This would not be the major problem in developed nations, where biomass as a source for thermal energy and raw materials for industrial processes has recently gained increased attention as a renewable and greenhouse-friendly commodity. Hence, sustainable management is required to prevent adverse consequences for society and the environment. Paradoxically biomass is tagged to be sustainable per se, although this is by no means substantiated since it depends on the local conditions and management used. Compared to conventional fossil sources of energy where "sustainability" is only directed at a wise and efficient use of a finite resource, sustainability of biomass from forests has to be considered in a much wider context. Biomass represents just one of a multitude of other ecosystem services and the potential for its provision depends on the conditions of any given ecosystem. As a matter of fact, ecosystems are extremely heterogeneous from global to forest stand scale, mainly controlled by environmental conditions, such as climate, soils and resulting species composition and anthropogenic impacts. Likewise, society's demands for specific ecosystem services are highly diverse. While recreation and the provision of a clean

\footnotetext{
* See http://satoyama-initiative.org/en/ for more details.
} 
environment (water, air) are likely the most important service close to urban areas and settlements, the provision of wood and by-products as economic commodities might be important in more remote, but accessible regions. This also implies one of the major differences to the current energy system. Besides the fact that bio-energy is not capable of providing the same amount of sustainable energy we are currently receiving from fossil fuels, the infrastructure has to be decentralized, directed at local demands and supplies. Both, the economic stability as well as the benefits for environment and society are at risk in the case of large-scale bioenergy power plants. Based on a global review, Lattimore et al. [58] identified six main areas of environmental constraints with regard to wood fuel production:

1. Soils

2. Hydrology and water quality

3. Site productivity

4. Forest biodiversity

5. Greenhouse gas balances

6. Global and supply-chain impacts of bioenergy production

This listing elucidates the challenge of applying sustainability criteria to biomass production, since a large set of criteria and indicators for bioenergy production systems has to be implied. Consequently, sustainability comes at the cost of a high complexity of ensuring mechanisms. Nonetheless, a set of regionally adaptable principles, criteria, indicators and verifiers of sustainable forest management, as suggested by Lattimore et al. [58] might be inevitable to ensure best practices according to the current status of scientific knowledge. They propose an adaptive forest management framework with continuous monitoring in certification systems to ensure efficacy and continual improvement. Policy has to ensure that such regulations are implemented in binding regulations. Corruption and greed for short-term profit maximization are still major problems, providing a base for unsustainable use of resources, especially in countries with unstable political situations. Apart from the general challenges of biomass production, we showed a number of examples of different Quercus dominated forest management systems and their considerations for sustainable biomass production.

Short rotation woody crops (SRWC) have the potential to maximize biomass production, which comes at certain environmental costs. Utilizing the maximum possible increment, by using fast growing species including Quercus and by reducing rotation periods, soils have to provide substantial amounts of nutrients, which must be returned by fertilization. Economic considerations (economies of scale) and high levels of mechanization lead to uniform structures and monocultures. Hence, biodiversity and a number of other ecosystem services are threatened. Fertilization in agriculture is always associated with considerations of groundwater pollution. Likewise, fertilization can have the same effects in SRWC if soil properties are ignored and improper fertilization strategies are applied. However, there are indications that SRWC may better utilize the nutrients from fertilization and leaching could be minimized [36]. This might be a consequence of perennial crops in comparison to conventional crops in agriculture and deeper rooting of the biomass crops. However, 
another potential problem linked to agriculture is the fact that SRWC are often established on former agricultural land. Together with the trend towards other kinds of agrarian nonwoody biomass crops for energy production (biofuels, biogas), it should be noted that agricultural land should be given priority for food and feed production under current predictions for population growth. This conversion of use is especially problematic in some developing countries and was recently discussed extensively [59].

Quercus dominated high forest (HF) represents a system of conventional forestry and it was expedited as a consequence of reduced demands for fuelwood and charcoal as they were substituted by fossil sources of energy. Another reason was increasing demands for higher timber qualities for construction and trade. This reversal in forest management towards longer rotation periods of $>100$ years in combination with limited utilization of small diameter compartments such as branches and twigs resulted in improving soil conditions in many cases in Europe, especially close to urban areas. However, the potential for biomass production for energetic utilization is limited as this system aims at biomass refinement rather than maximizing outputs in terms of quantities. Potential sources for bioenergy production are harvests of silvicultural interventions (thinning) as well as crown and stump biomass at the end of the rotation period. We showed that crown biomass removal in addition to stem utilization (full tree harvest) will extract $50 \%$ more $\mathrm{N}$ as compared to stemonly harvesting. On the contrary, stem debarking could retain $70 \%$ of the total aboveground $\mathrm{N}$ pool in the system under a scenario of stem-only extraction. In accordance with aboveground stand development, the root-to-shoot ratio follows a distinct pattern. While the woody vegetation invests more in root growth in the youngest stand to explore soil nutrient and water reserves, the ratio reaches a value below 1 (i.e. aboveground biomass prevails) in the 32 year old HF stand and subsequently levels off. This observation was supported by the N:P ratio in the youngest HF indicating $\mathrm{N}$ limitations, potentially priming root growth. In general, the biomass potential for energetic utilization is lower as compared to the CS system, which is mainly expressed by higher NPP as a consequence of more fertile soils and different management aims. If more intensive biomass extractions are considered to be sustainable or not therefore depends on soil nutrient and water budgets and has to be assessed at a local scale. Our HF sites showed sufficient nutrient pools despite some indication for $\mathrm{N}$ deficiency in the youngest plot.

Coppice with standards (CS) holds an intermediate position between SRWC and HF. It is capable of providing both higher quality timber logs and biomass for energetic utilization. The system has a long tradition in our study region and it is very flexible concerning different demands of the respective qualities and quantities. It was demonstrated that CS has the advantage of a fully functional root system at all times during the rotational cycles which is represented in the relatively stable root-to-shoot ratio and this is an advantage in relatively dry climates. Re-sprouting occurs relatively fast and is likely to be more successful as compared to planting or natural generative regeneration, especially under conditions of seasonal droughts. However, standards also act as seed trees where genetic selection is possible (promotion of individuals with high stem quality). They act as a backup if vegetative regeneration is unsuccessful and provide shade during summer. Nutritional bottlenecks are not expected 
under current management practices as the soils in our CS plots are relatively fertile and the forestland is surrounded by extensively managed agricultural land. However, if the management strategy is changed towards schemes of increased biomass extraction, the effects on soils have to be studied in order to ensure sustainability.

The Satoyama woodlands in Japan are an example of traditional sustainable woodland management, carefully balancing ecosystem services in regions with relatively high population density, thus implying a high level of social-nature interaction. Since this form of landscape management proved to be successful over centuries with a high degree of flexibility with regard to changing demands over time, it might be a model of sustainable land use for other regions in the world. However, the effects of cyclic litter removal from soil nutrient pools should be investigated since we demonstrated that foliage is the compartment holding the highest contents of macronutrients.

A sustainable future, entirely based on renewable sources of energy without harming our environment is possible. It will certainly base on decentralized structures with a large pool of different sources of renewable energy, which has another great advantage of a high level of resilience in comparison to our current system. Biomass can play a significant role in areas with sufficient supplies, as long as the production follows sustainability criteria and does not interfere with other environmental services essential for that region. The optimal future energy system consists of a range of different sources, in which biomass is eligible along with other renewable sources as long as it is produced in a sustainable manner. Certainly, changing lifestyles (reduced energy consumption, less meat in diets, higher efficiency) especially in the developed regions of the world may be a very important and effective step to reducing resource consumption, which should be taken immediately.

\section{Author details}

Viktor J. Bruckman* and Gerhard Glatzel

Austrian Academy of Sciences (ÖAW),

Commission for Interdisciplinary Ecological Studies (KIOES), Vienna, Austria

Shuai Yan

Northwest Agricultural and Forestry University, College of Forestry, Yangling, China

Eduard Hochbichler

University of Natural Resources and Life Sciences (BOKU), Institute of Silviculture, Vienna, Austria

\section{Acknowledgement}

This study was funded by the Austrian Federal Ministry of Agriculture, Forestry, Environment and Water Management (Project No. 100185) and the Austrian Academy of Sciences (ÖAW), Commission for Interdisciplinary Ecological Studies (KIÖS) (Project No.

${ }^{*}$ Corresponding Author 
P2007-07). We would like to thank Robert Jakl and Stephan Brabec for their unremitting support in fieldwork and lab analysis as well as Yoseph Delelegn and Arnold Bruckman for their invaluable efforts in collecting samples in the field. Toru Terada enriched our study with valuable discussions on coppice management in Japan. We would further like to express our gratitude to Christina Delaney for proofreading of the manuscript.

\section{References}

[1] Le Quere C, Raupach MR, Canadell JG, Marland G, et al. Trends in the sources and sinks of carbon dioxide. Nature Geosci. [10.1038/ngeo689]. 2009;2(12):831-6.

[2] International Energy Agency. World Energy Outlook 2011 - Executive Summary. Paris: OECD Publishing; 2011.

[3] Kiehl JT, Trenberth KE. Earth's Annual Global Mean Energy Budget. Bulletin of the American Meteorological Society. 1997 1997/02/01;78(2):197-208.

[4] Peters G, Marland G, Le Quéré C, Boden T, Canadell P, Raupach M. An update of the global carbon budget: Emissions rebound after the Global Financial Crisis (GFC). Planet under Pressure 2012; London, UK, 2012.

[5] Tans P. Trends in Atmospheric Carbon Dioxide. National Oceanic and Atmospheric Administration (NOAA), Earth System Research Laboratory (ESRL), USA; 2012.

[6] Neftel A, Moor E, Oeschger H, Stauffer B. Evidence from polar ice cores for the increase in atmospheric $\mathrm{CO}_{2}$ in the past two centuries. Nature. [10.1038/315045a0]. 1985;315(6014):45-7.

[7] Plass GN. The Carbon Dioxide Theory of Climatic Change. Tellus. 1956;8(2):140-54.

[8] Canadell JG, Le Quéré C, Raupach MR, Field CB, Buitenhuis ET, Ciais P, et al. Contributions to accelerating atmospheric $\mathrm{CO}_{2}$ growth from economic activity, carbon intensity, and efficiency of natural sinks. P Natl Acad Sci USA. 2007 November 20, 2007;104(47):18866-70.

[9] Lambin EF, Meyfroidt P. Global land use change, economic globalization, and the looming land scarcity. P Natl Acad Sci USA. 2011 Mar 1;108(9):3465-72.

[10] Pan Y, Birdsey RA, Fang J, Houghton R, Kauppi PE, Kurz WA, et al. A Large and Persistent Carbon Sink in the World's Forests. Science. 2011 August 19, 2011;333(6045):988-93.

[11] Nabuurs GJ, Thurig E, Heidema N, Armolaitis K, Biber P, Cienciala E, et al. Hotspots of the European forests carbon cycle. Forest Ecology and Management. 2008 Jul 30;256(3):194-200.

[12] Vetter M, Wirth C, Bottcher H, Churkina G, Schulze ED, Wutzler T, et al. Partitioning direct and indirect human-induced effects on carbon sequestration of managed coniferous forests using model simulations and forest inventories. Global Change Biology. 2005 May;11(5):810-27.

[13] Bruckman VJ, Yan S, Hochbichler E, Glatzel G. Carbon pools and temporal dynamics along a rotation period in Quercus dominated high forest and coppice with standards stands. Forest Ecology and Management. 2011;262(9):1853-62. 
[14] Don A, Bärwolff M, Kalbitz K, Andruschkewitsch R, Jungkunst HF, Schulze E-D. No rapid soil carbon loss after a windthrow event in the High Tatra. Forest Ecology and Management. 2012;276(0):239-46.

[15] Schuur EAG, Abbott B. Climate change: High risk of permafrost thaw. Nature. [10.1038/480032a]. 2011;480(7375):32-3.

[16] Schmidt MWI, Torn MS, Abiven S, Dittmar T, Guggenberger G, Janssens IA, et al. Persistence of soil organic matter as an ecosystem property. Nature. 2011 Oct 6;478(7367):49-56.

[17] Rumpel C, Kogel-Knabner I, Bruhn F. Vertical distribution, age, and chemical composition of organic, carbon in two forest soils of different pedogenesis. Org Geochem. 2002;33(10):1131-42.

[18] Diochon A, Kellman L, Beltrami H. Looking deeper: An investigation of soil carbon losses following harvesting from a managed northeastern red spruce (Picea rubens Sarg.) forest chronosequence. Forest Ecology and Management. 2009 Jan 31;257(2):413-20.

[19] Matthews R, Grogan P. Potential C-sequestration rates under short-rotation coppiced willow and Miscanthus biomass crops: a modelling study. Aspects of Applied Biology. 2001;65:303-312.

[20] Grogan P, Matthews R. A modelling analysis of the potential for soil carbon sequestration under short rotation coppice willow bioenergy plantations. Soil Use and Management. 2002 Sep;18(3):175-83.

[21] Richter DD, Markewitz D, Trumbore SE, Wells CG. Rapid accumulation and turnover of soil carbon in a re-establishing forest. Nature. 1999;400:56-8.

[22] Rasse D, Rumpel C, Dignac M-F. Is soil carbon mostly root carbon? Mechanisms for a specific stabilisation. Plant and Soil. 2005;269(1):341-56.

[23] Godbold D, Hoosbeek M, Lukac M, Cotrufo M, Janssens I, Ceulemans R, et al. Mycorrhizal Hyphal Turnover as a Dominant Process for Carbon Input into Soil Organic Matter. Plant and Soil. 2006;281(1):15-24.

[24] Jha P, Prasad Mohapatra K. Leaf litterfall, fine root production and turnover in four major tree species of the semi-arid region of India. Plant and Soil. 2010;326(1):481-91.

[25] Schulze E-D, Wirth C, Heimann M. Managing Forests After Kyoto. Science. 2000 September 22, 2000;289(5487):2058-9.

[26] Knohl A, Schulze ED, Kolle O, Buchmann N. Large carbon uptake by an unmanaged 250-year-old deciduous forest in Central Germany. Agricultural and Forest Meteorology. 2003 Sep 30;118(3-4):151-67.

[27] Luyssaert S, Schulze ED, Borner A, Knohl A, Hessenmoller D, Law BE, et al. Oldgrowth forests as global carbon sinks. Nature. [10.1038/nature07276]. 2008;455(7210):213-5.

[28] Schulp CJE, Nabulars GJ, Verburg PH, de Waal RW. Effect of tree species on carbon stocks in forest floor and mineral soil and implications for soil carbon inventories. Forest Ecology and Management. 2008 Jul 30;256(3):482-90.

[29] Seidl R, Rammer W, Jager D, Currie WS, Lexer MJ. Assessing trade-offs between carbon sequestration and timber production within a framework of multi-purpose forestry in Austria. Forest Ecology and Management. 2007 Aug 30;248(1-2):64-79. 
[30] Wiseman CLS. Organic Carbon Sequestration in Soils: An Investigation of Five Profiles in Hesse, Germany [Dissertation]. Frankfurt am Main: Johann Wolfgang Goethe Universität; 2003.

[31] Van Belle JF. A model to estimate fossil $\mathrm{CO}_{2}$ emissions during the harvesting of forest residues for energy-with an application on the case of chipping. Biomass \& Bioenergy. 2006 Dec;30(12):1067-75.

[32] Glatzel G. The impact of historic land use and modern forestry on nutrient relations of Central European forest ecosystems. Nutr Cycl Agroecosys. 1991;27(1):1-8.

[33] Terada T, Yokohari M, Bolthouse J, Tanaka N. Refueling Satoyama Woodland Restoration in Japan: Enhancing Restoration Practice and Experiences through Woodfuel Utilization. Nature and Culture. 2010;5(3):251-76.

[34] Salon C, Avice J-C, Alain O, Prudent M, Voisin A-S. Plant N Fluxes and Modulation by Nitrogen, Heat and Water Stresses: A Review Based on Comparison of Legumes and Non Legume Plants. In: Shanker AK, Wenkateswarlu B, editors. Abiotic Stress in Plants - Mechanisms and Adaptations: Intech Science; 2011.

[35] Dickmann DI. Silviculture and biology of short-rotation woody crops in temperate regions: Then and now. Biomass \& Bioenergy. 2006 Aug-Sep;30(8-9):696-705.

[36] Aronsson PG, Bergstrom LF, Elowson SNE. Long-term influence of intensively cultured short-rotation Willow Coppice on nitrogen concentrations in groundwater. Journal of Environmental Management. 2000 Feb;58(2):135-45.

[37] Garten J, C.T., Wullschleger SD, Classen AT. Review and model-based analysis of factors influencing soil carbon sequestration under hybrid poplar. Biomass \& Bioenergy. 2011;35:214-26.

[38] Trap J, Bureau F, Vinceslas-Akpa M, Chevalier R, Aubert M. Changes in soil N mineralization and nitrification pathways along a mixed forest chronosequence. Forest Ecology and Management. 2009;258:1284-92.

[39] Hochbichler E. Methods of oak silviculture in Austria. Annals of Forest Science. 1993;50(6):583-91.

[40] Frank J. Der Hochleithenwald, Einführung in die Wälderschau des Niederösterreichischen Forstvereins 1937 in das Rudolf Graf von Abensberg und Traunsche Forstrevier Wolkersdorf: Selbstverlag des NÖ. Forstvereins. 1937.

[41] Nyland RD. Silviculture: concepts and applications. 2. ed. New York: McGraw-Hill; 2002.

[42] Hochbichler E. Fallstudien zur Struktur, Produktion und Bewirtschaftung von Mittelwäldern im Osten Österreichs (Weinviertel). Wien: Österr. Ges. für Waldökosystemforschung und Experimentelle Baumforschung Univ. für Bodenkultur; 2008.

[43] IUSS Working Group WRB. World reference bases for soil resources 2006. Rome: FAO2006.

[44] Hochbichler E, Bruckman VJ, Spinka S, Glatzel G, Grieshofer H. Untersuchungen zur Dynamik der Biomassen- und Kohlenstoffvorräte in Niederwäldern mit Überhälter, Mittel- und Hochwäldern. Vienna: University of Natural Resources and Life Sciences, Department for forest and soil sciences 2009. Report No.: 100185. 
[45] Pickett STA. Space-for-time substitutions as an alternative to long-term studies. In: Likens GE, editor. Long-term Studies in Ecology. New York: Springer; 1989. p. 110-35.

[46] Walker LR, Wardle DA, Bardgett RD, Clarkson BD. The use of chronosequences in studies of ecological succession and soil development. J Ecol. 2010 Jul;98(4):725-36.

[47] Englisch M. Österreichische Waldboden-Zustandsinventur. Teil III: Atmogene Hauptnährstoffe. Österreichische Waldboden-Zustandsinventur Ergebnisse. Vienna: Forstliche Bundesversuchsanstalt; 1992. 247 pages.

[48] Chemical analyses of soils - Extraction of elements with aqua regia or nitric acid perchloric acid mixture, ÖNORM L 1085 (1999).

[49] Bormann FH, Likens GE. Pattern and process in a forested ecosystem disturbance, development and the steady state based on the Hubbard Brook ecosystem study. New York: Springer; 1979.

[50] Santantonio D, Hermann RK. Standing crop, production, and turnover of fine roots on dry, moderate, and wet sites of mature Douglas-fir in western Oregon. Annals of Forest Science. 1985;42(2):113-42.

[51] Noguchi K, Konopka B, Satomura T, Kaneko S, Takahashi M. Biomass and production of fine roots in Japanese forests. J Forest Res-Jpn. 2007 Apr;12(2):83-95.

[52] Gärdenäs AI, Ågren GI, Bird JA, Clarholm M, Hallin S, Ineson P, et al. Knowledge gaps in soil carbon and nitrogen interactions - From molecular to global scale. Soil Biology and Biochemistry. 2011;43(4):702-17.

[53] Andre F, Ponette Q. Comparison of biomass and nutrient content between oak (Quercus petraea) and hornbeam (Carpinus betulus) trees in a coppice-with-standards stand in Chimay (Belgium). Annals of Forest Science. 2003 Sep;60(6):489-502.

[54] Heilman P, Norby RJ. Nutrient cycling and fertility management in temperate short rotation forest systems. Biomass and Bioenergy. 1998;14(4):361-70.

[55] Morimoto Y. What is Satoyama? Points for discussion on its future direction. Landscape and Ecological Engineering. 2011;7(2):163-71.

[56] Knight C. The Discourse of "Encultured Nature" in Japan: The Concept of Satoyama and

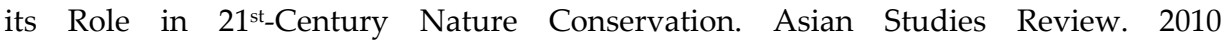
2010/12/01;34(4):421-41.

[57] Yokohari M, Bolthouse J. Keep it alive, don't freeze it: a conceptual perspective on the conservation of continuously evolving "Satoyama" landscapes. Landscape and Ecological Engineering. 2011;7(2):207-16.

[58] Lattimore B, Smith CT, Titus BD, Stupak I, Egnell G. Environmental factors in woodfuel production: Opportunities, risks, and criteria and indicators for sustainable practices. Biomass and Bioenergy. 2009;33(10):1321-42.

[59] Winiwarter V, Gerzabek MH, editors. The Challenge of sustaining soils: Natural and social ramifications of biomass production in a changing world. Vienna: Austrian Academy of Sciences Press; 2012. 